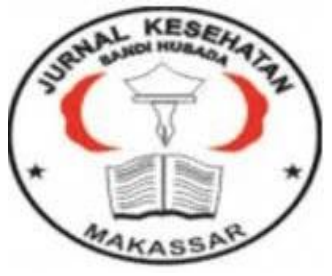

Jurnal Ilmiah Kesehatan Sandi Husada

hhttps://akper-sandikarsa.e-journal.id/JIKSH

Volume 9, Nomor 2, Desember 2020, pp 848-852

p-ISSN: 2354-6093 dan e-ISSN: 2654-4563

DOI: $10.35816 /$ jiskh.v10i2.411

\title{
Asuhan Keperawatan Penerapan Luka Lembab Pada Pasien Diabetes Mellitus
}

Nursing Care Application of Moist Wounds in Diabetes Mellitus Patients

Indah Dewi Ridawati ${ }^{1}$, Muhammad Rivaldy Elvian ${ }^{2}$

12 Keperawatan, Poltekkes Kemenkes Palembang

\section{Artikel info \\ Artikel history: \\ Received; Agustus 2020 \\ Revised;September 2020 \\ Accepted;September2020}

\begin{abstract}
Abstrak
Ulkus diabetikum adalah salah satu komplikasi diabetes yang sering dijumpai.Teknik perawatan luka lembab dan tertutup adalah metode untuk mempertahankan kelembaban luka dengan menggunakan bahan balutan penahan kelembaban sehingga menyembuhkan luka, pertumbuhan jaringan dapat terjadi secara alami. Tujuan penelitian ini untuk mengetahui tentang keefektifan penerapan perawatan luka lembab untuk mengatasi gangguan integritas jaringan di ruang Al-Kautsar Rumah Sakit Siti Aisyah Kota Lubuklinggau. Subjek dalam penelitian ini adalah 2 orang dewasa dengan Ulkus grade 0 2. Perlakuan dilakukan secara langsung dengan pengkajian awal pada pasien ulkus diabetikum dan selanjutnya intervensi penerapan perawatan luka lembab pada luka ulkus untuk memperbaiki jaringan pada luka ulkus. Hasil penelitian diketahui bahwa setelah dilakukan intervensi keperawatan selama 3 hari secara berturut-turut terjadi pertumbuhan jaringan yang lebih cepat dari waktu penyembuhan dengan menggunakan obat lain maupun tehnik lain. Kepada institusi pelayanan kesehatan diharapkan dapat meningkat kualitas asuhan keperawatan yang berfokus pada pasien dengan terus mengoptimalkan SOP dalam setiap melakukan tindakan keperawatan.
\end{abstract}

\footnotetext{
Abstract

Diabetic ulcer is one of the complications of diabetes that is often encountered. Moist and closed wound care technique is a method to maintain wound moisture by using moisture retardant dressing material to heal wound, tissue growth can be done naturally. The purpose of this study was to study the effectiveness of applying moist wound care and tribal ointment to overcome tissue safety problems in the AlKautsar room at Siti Aisyah Hospital, Lubuklinggau City. The subjects in this study were 2 adults with a diagnosis of Type
} 
II Diabetes Mellitus with grade 0-2 Ulcers. The treatment was carried out directly with the initial assessment of diabetic ulcer patients and subsequently the intervention of the application of wound care to ulcer wounds to repair tissue in ulcer wounds. The results of the study revealed that after nursing interventions for 3 consecutive days tissue growth was faster than the time of recovery using other drugs and other techniques. It is expected that health care can improve the quality of nursing care needed for patients by continuing to improve SOPs in every nursing action.

Keywords:
Diabetes Melitus;
Luka Ulkus;
Luka Lembab;

Coresponden author:

Email: indahdewiridawati@gmail.com

artikel dengan akses terbuka dibawah lisensi CC BY 4.0

\section{Pendahuluan}

Dari hasil survei International Diabetes Federation (IDF, 2015) menunjukkan bahwa penderita DM di dunia berjumlah 415 juta jiwa, meninggal akibat DM berjumlah 5 juta jiwa. Satu dari 11 orang dewasa menderita DM, jenis kelamin laki-laki yang menderita DM berjumlah 215.2 juta jiwa sedangkan perempuan berjumlah 199.5 juta jiwa. Tingkat kejadian orang yang menderita DM menurut IDF di Indonesia mencapai 10 juta jiwa dan menduduki peringkat ke-7 dunia dimana peringkat pertama adalah China. Jumlah penduduk Indonesia yang menderita DM di tahun 2040 diperkirakan mencapai angka \pm 642 juta jiwa. Teknik perawatan luka lembab dan tertutup atau yang dikenal dengan "moist wound healing" adalah metode untuk mempertahankan kelembaban luka dengan menggunakan bahan balutan penahan kelembaban sehingga menyembuhkan luka, pertumbuhan jaringan dapat terjadi secara alami. Munculnya konsep "moist wound healing" menjadi dasar munculnya pembalut luka modern Mutiara, 2009 dalam (Septiyanti, 2014).

Penerapan perawatan luka modern mengalami perkembangan perawatan luka modern dengan menggunakan Wundres sesuai dengan SOP dapat meningkatkan kelembaban luka sehingga mempercepat proses penyembuhan luka. Sehingga dapat dijadikan salah satu metode baru dalam menyelesaikan masalah keperawatan yaitu kerusakan integritas jaringan kulit. Khususnya pada pasien DM dengan luka ganggren (Wijayanti, 2016). Meningkatnya jumlah responden diabetes mellitus meyebabkan peningkatan kejadian komplikasi diabetes, salah satunya yaitu ulkus Diabetes Mellitus. Berdasar data hydrogel terbukti efektif dalam meregenerasi luka. Hydrogel terbukti efektif dalam meregenerasi luka, namun terdapat perbedaan pada kedua responden karena beberapa faktor yaitu nutrisi, lama mengalami luka, dan usia(Purwaningrum Mita, Wahyuni, \& Hermawati, 2019). Menurut (Detty, dkk, 2020) bahwa ciri ulkus diabetikum didominasi oleh wanita pada usia lanjut lanjut dan rata-rata penderita maag memiliki riwayat keluarga diabetes melitus, dirawat pada 0-5 hari, dan terapinya digunakan dengan pembedahan.

Hasil penelitian (Saputri, 2020) berdasarkan komplikasi akut KAD pada 6 pasien (8,3\%), hipoglikemia pada 8 pasien $(11,1 \%)$. Komplikasi mikrovaskuler adalah retinopati pada 8 pasien $(11,1 \%)$, nefropati pada 11 pasien $(15,3 \%)$, neuropati pada 5 pasien $(6,9 \%)$. Komplikasi makrovaskular adalah 3 pasien serebrovaskular (4,2\%), penyakit jantung koroner 8 pasien $(11,1 \%)$, dan ulkus 20 pasien $(27,8 \%)$. 
Teknik perawatan luka yang dipakai di Rumah Sakit Siti Aisyah Kota Lubuklinggau menggunakan kassa dan cairan $\mathrm{NaCl}$ 0,9\%. Kassa diberikan cairan $\mathrm{NaCl}$ lalu ditempelkan menggunakan plaster, lalu didiamkan selama 1 hari. Tehnik ini dilakukan setiap 1 hari sekali tiap pagi. Kekurangan dari teknik perawatan luka ini adalah luka lebih mudah terkena agen bakteri dari luar sehingga menimbulkan resiko infeksi. Sedangkan kelebihannya adalah biayanya yang murah.

\section{Metode}

Jenis penelitian deskriptif dalam bentuk studi kasus yang merupakan penelitian untuk mengumpulkan dan menggambarkan informasi mengenai status subyek penelitian kemudian menghimpun dan menganalisis data berkenan dengan kasus yang diangkat selanjutnya dituangkan dalam bentuk asuhan keperawatan. Desain yang dipilih adalah studi kasus berupa pendekatan asuhan keperawatan secara komprehensif sesuai proses keperawatan (pengkajian, diagnosis, intervensi, implementasi dan evaluasi). Populasinya adalah semua pasien yang mengalami ulkus diabetikum pada pasien Diabetes Mellitus di Ruangan Al Kautsar RSUD Siti Aisyah Kota Lubuklinggau pada bulan Mei dengan sampel penelitian dari tanggal 20 - 27 Mei 2019 berjumlah dua pasien yang dipilih menjadi subjek. Variabel independen adalah gangguan integritas jaringan kulit dan variabel dependen adalah perawatan luka lembab pasien diabetes mellitus.

Metode pengumpulan data yang digunakan adalah dengan observasi terhadap derajat ulkus pada pasien diabetes militus sebelum dan sesudah pemberian Penerapan Luka Lembab pada ulkus diabetikum. Instrumen studi kasus yang digunakan penulis pada studi kasus ini adalah SOP Perawatan Luka Lembab dan instrumen pengukur kerusakan integritas jaringan menggunakan skala Bates Jansen, lembar ceklist dan format pengkajian keperawatan Medikal Bedah yang memuat tanda-tanda masalah kerusakan integritas jaringan yang diamati, yang dirancang oleh penulis sesuai tujuan yang diinginkan.

\section{Hasil Dan Pembahasan}

Dalam studi kasus ini dipilih dua orang sebagai subjek studi kasus yaitu: Subjek I dan Subjek II. Kedua subjek ini sudah sesuai dengan kriteria yang telah ditetapkan.

\section{Subjek I}

Subjek I dengan initial Ny. K, berusia 62 tahun, Jenis kelamin perempuan, beragama islam, pendidikan terakhir SMA, pekerjaan ibu rumah tangga, keluhan luka dikaki kanan sulit sembuh, bernanah, kulit sekitar area luka terkelupas, nyeri dan sulit beraktivitas. TD : 100 / $70 \mathrm{mmHg}$, RR : 23 x / menit, Nadi : 76 x / menit, temp : 36,7 oC. Tanggal masuk Rumah Sakit 20 Mei 2019.

\section{Subjek II}

Subjek II dengan initial Ny. M, berusia 62 tahun, Jenis kelamin perempuan, beragama islam, pendidikan terakhir SMP, pekerjaan petani, keluhan nyeri di area luka kaki sebelah kiri, luka berbau, berwarna kemerahan, terasa gatal dan sulit beraktivitas. TD: 110 / 80 mmHg, RR : 22 x / menit, Nadi : 84 x / menit, Temp : 36,5 oC. Kurang nafsu makan dan mual. Tanggal masuk Rumah Sakit 27 Mei 2019.

Pada subjek I diketahui bahwa terjadi perubahan yang cukup signifikan mengenai skala luka ataupun kondisi luka setelah dilakukan intervensi keperawatan penerapan perawatan luka lembab pada hari pertama sebelum dilakukan penerapan perawatan luka lembab didapati, klien mengeluh luka sulit sembuh, berbau, terasa nyeri,skala luka 23, ukuran luka : panjang $10 \mathrm{~cm}$ dan lebar $7 \mathrm{~cm}$, perdara han minimal, batas tepi luka tidak menyatu dengan dasar luka dan kulit sekitar luka berwarna kemerahan setelah dilakukan penerapan perawatan luka lembab selama 3 hari pada pasien ulkusdidapati luka tidak 
berbau, nyeri berkurang, skala luka 15, ukuran luka : panjang $9 \mathrm{~cm}$ dan $6 \mathrm{~cm}$, perdarahan pada luka hilang, batas tepi luka sudah menyatu dengan dasar luka dan kulit sekitar luka berwarna pink.

Pada subjek II diketahui bahwa terjadi perubahan yang juga cukup signifikan pada skala luka setelah dilakukan intervensi keperawatan penerapan perawatan luka lembab pada pasien ulkus di ruang rawat inap, pada hari pertama sebelum dilakukan penerapan penerapan perawatan luka lembab pada ulkus didapati klien mengatakan luka sulit sembuh, luka berbau, terasa nyeri dan gatal, skala luka 22, ukuran luka : panjang $6 \mathrm{~cm}$ dan lebar $5 \mathrm{~cm}$, tidak ada perdarahan, batas tepi luka tidak menyatu dengan dasar luka dan kulit sekitar luka masih berwarna agak kemerahan setelah dilakukan penerapan perawatan luka lembab selama 3 hari pada pasien ulkus didapati luka tidak berbau, nyeri berkurang serta tida terasa gatal, skala luka 15, ukuran luka : panjang $5 \mathrm{~cm}$ dan lebar 5 $\mathrm{cm}$, tidak ada perdarahan, batas tepi luka sudah menyatu dengan dasar luka dan kulit sekitar luka masih berwarna pink.

Penelitian Penerapan Perawatan Luka Lembab pada pasien ulkus diabetik di ruang rawat inap RSUD Siti Aisyah yang dilakukan pada subjek I dan subjek II terbukti efektif. Dapat dilihat dari nyeri yang berkurang, resiko infeksi teratasi dan perubahan luka yang cukup membaik. Namun perubahan lukanya belum dapat sembuh total dikarnakan kendala waktu penelitian hanya 3 hari, sedangkan luka dapat sembuh dalam kurun waktu 4 - 6 minggu.

(Oktarina, 2016) berpendapat perawatan luka dengan menggunakan modern dressing mulai berkembang di Indonesia. Perubahan tersebut dapat dilihat dari sebelumnya sebagian besar perawat percaya penyembuhan luka yang terbaik membuat lingkungan luka tetap kering mulai berubah menjadi perawatan luka dengan metode moisture balance. Menurut (Mulyadi \& Nurrahmawati, 2018) bahwa konsep perawatan luka lembab berbasis (Moisture Balance) telah lama dikenal di dunia, karena memiliki keunggulan seperti mempercepat re-epitalisasi, mempertahankan kelembaban, mengurangi infeksi, pengeluaran kelembaban alas luka dapat merangsang faktor pertumbuhan yang mempercepat pertumbuhan proses penyembuhan luka.

Madu memiliki sifat anti bakteri, anti virus, anti jamur, anti oksidan dan anti inflamasi serta berperan untuk menjaga keseimbangan kelembaban di lokasi luka dan juga memiliki pelindung pelindung untuk meminimalkan kontak luka dan agen infeksi. Penggunaan madu sebagai pembalut terbukti efektif dan mempersingkat masa penyembuhan ulkus diabetes. Penggunaan madu efektif sebagai balutan pengobatan untuk penyembuhan ulkus kaki diabetik (Regia Divandra, 2020).

Hasil penelitian (Naralia \& Ariani, 2018) menunjukkan bahwa 50\% responden memiliki pengetahuan yang cukup, namun masih ada sebanyak $31,7 \%$ responden yang memiliki pengetahuan yang kurang tentang perawatan luka dengan metode moist wound healing. Menurut Penelitian (Ose, Utami, \& Damayanti, 2018) perawatan luka pada ulkus diabetik dengan teknik moist healing lebih cepat proses penyembuhannya sehingga pasien mendapatkan perawatan lebih efektif dan efisien baik dari segi waktu dan biaya.(Kamal, 2015) Berpendapat bahwa penatalaksanaan luka terkini adalah prinsip lembab, yaitu luka dikondisikan tertutup dan diiringi aplikasi perban dengan menggunakan obat yang dapat mempercepat penyembuhan luka. 


\section{Simpulan Dan Saran}

Hasil pengkajian didapatkan keluhan utama pasien luka kaki yang lama sembuh. Masalah keperawatan yang utama ditegakkan adalah gangguan integritas jaringan/ kulit. Dalam perencanaan penulis menentukan prioritas tindakan yang tepat dalam proses keperawatan ulkus diabetik. Pada tahap ini intervensi yang dilaksanakan disesuaikan dengan intervensi yang terdapat dalam teori. Tahap pelaksanaan asuhan keperawatan $\mathrm{Ny}$. $\mathrm{M}$ dan Ny.K didasarkan pada perencanaan yang telah disusun penulis bersama klien dan keluarga. Dalam mengevaluasi proses keperawatan pada klien dengan ulkus diabetik selalu mengacu pada tujuan pemenuhan kebutuhan klien. Hasil evaluasi yang dilakukan selama tiga hari menunjukkan nyeri yang berkurang, resiko infeksi teratasi dan perubahan luka yang cukup membaik.

Kepada masyarakat yang mengalami atau mempunyai anggota keluarga yang memiliki ulkus diabetik dapat merekomendasikan diri untuk dirawat menggunakan perawatan luka lembab. Untuk pihak lahan praktek, supaya melanjutkan pelaksanaan perawatan luka lembab dan melakukan penelitian lanjutan mengenai perawatan luka lembab pada pasien dengan ulkus diabetik.

\section{Daftar Rujukan}

Detty, A. U., Fitriyani, N., Prasetya, T., \& Florentina, B. (2020). Karakteristik Ulkus Diabetikum Pada Penderita Diabetes Melitus. Jurnal Ilmiah Kesehatan Sandi Husada, 11(1), 258-264.

Kamal, S. (2015). Implementasi Perawatan Luka Modern Di Rs Harapan Magelang. Prosiding Seminar Nasional \& Internasional.

Mulyadi, E., \& Nurrahmawati, N. (2018). Modern Wound Care Management In General Hospital Cut Nyak Dien Langsa. Indonesian Nursing Journal Of Education And Clinic (INJEC), 1(1), 24-30.

Naralia, T. W., \& Ariani, Y. (2018). Pengetahuan Perawat Tentang Perawatan Luka Dengan Metode Moist Wound Healing di RSUD H. Adam Malik Medan. Talenta Conference Series: Tropical Medicine (TM), 1(1), 75-79.

Oktarina, E. (2016). Aplikasi modern wound care pada perawatan luka infeksi di rs pemerintah kota padang. Ners Jurnal Keperawatan, 12(2), 159-165.

Ose, M. I., Utami, P. A., \& Damayanti, A. (2018). Efektivitas perawatan luka teknik balutan wet-dry dan moist wound healing pada penyembuhan ulkus diabetik. Journal of Borneo Holistic Health, 1(1).

Purwaningrum Mita, S., Wahyuni, E. S., \& Hermawati, H. (2019). Penerapan Perawatan Luka Menggunakan Hydrogel Terhadap Proses Penyembuhan Luka Pada Pasien Dengan Ulkus Diabetes Mellitus Di Kecamatan Banjarsari.

Regia Divandra, C. V. (2020). Madu Sebagai Dressing Pada Penyembuhan Ulkus Diabetikum. Jurnal Ilmiah Kesehatan Sandi Husada, 11(1), 533-539.

Saputri, R. D. (2020). Komplikasi Sistemik Pada Pasien Diabetes Melitus Tipe 2. Jurnal Ilmiah Kesehatan Sandi Husada, 11(1), 230-236.

Septiyanti, M. (2014). Hubungan tingkat pengetahuan dengan sikap perawat tentang perawatan luka diabetes dengan menggunakan teknik moist wound healing. Program Studi Ilmu Keperawatan Universitas Riau.

Wijayanti, W. (2016). Penerapan Perawatan Luka Modern Dengan Wundres Pada Pasien Diabetes Mellitus Dengan Masalah Keperawatan Kerusakan Integritas Jaringan Kulit Di Ruang Azzara 2 Rsi Jemursari Surabaya. 